Claudine Kirsch* and Nikolaos Gogonas

\title{
Transnational experiences, language competences and worldviews: contrasting language policies in two recently migrated Greek families in Luxembourg
}

https://doi.org/10.1515/multi-2017-0017

Abstract: Against the backdrop of the ongoing crisis-led migration from Southern to Northwestern Europe, the present paper reports on a case study of two families who have recently migrated from Greece to Luxembourg. Luxembourg has a trilingual education system and many pupils of migrant background face difficulties on this account. Drawing on the framework of Family Language Policy, this paper explores the language ideologies and management strategies of two families as well as factors influencing their policies. This qualitative study was based on interviews, observations, and videos recorded by one of the families. The findings show that the families have contrasting language ideologies and management strategies that are informed by their differing transnational experiences, competences and worldviews. This study can contribute to a better understanding of the ways in which migrant families use their language resources in their new country.

Keywords: Greek migrants, Luxembourg, family language policies

\section{Introduction}

Since 2009, Southern Europeans have faced rampant unemployment and a dramatic fall in salaries and welfare allowances (Triandafyllidou and Gropas 2014). This is especially true of Greece, the country hardest hit by the economic crisis and by concomitant austerity measures (Labrianidis and Vogiatzis 2013). Like other Southern Europeans, thousands of Greeks have left the country over the past seven years. The majority headed for Northwestern Europe (Triandafyllidou and Gropas 2014). The migrating families have had to adapt to their new countries and

\footnotetext{
*Corresponding author: Claudine Kirsch, Faculte des Lettres des Sciences humaines des Arts et des Sciences de l'Education, University of Luxembourg, 11 Porte des Sciences, Esch-sur-Alzette 4366, Luxembourg, E-mail: claudine.kirsch@uni.lu

Nikolaos Gogonas, Faculty of English Language and Literature, University of Athens, Athens, Greece, E-mail: ngogonas@enl.uoa.gr
} 
are likely to face linguistic challenges. There is a rich research tradition of studying the ways in which parents promote language maintenance, for example in the field of family language policy (FLP). A FLP is the explicit and overt, or implicit and covert, but often dynamically changing mechanism that families use to plan language use and literacy practices among family members within home domains (King and Fogle 2013; Curdt-Christiansen 2013). Such policies are not neutral and must be understood within their wider socio-political, socio-economic and sociohistorical context. The present article investigates the language ideologies and language management of two Greek families.

There are several reasons why trilingual Luxembourg has been chosen as a research site. Firstly, very little research has been carried out on family language policies of transnational parents in Luxembourg. Exceptions are the studies by Made Mbe (2014) and Gogonas and Kirsch (2016). Secondly, the increasing Greek migration to this country and its trilingual education system from primary school onwards. Greek migration to Luxembourg started in the 1960s. At the time, the Greeks mainly came to work for NATO or as civil servants at European Institutions (Droulia-Mitrakou 2006). Owing to the economic crisis in Greece, emigration to Luxembourg has increased, especially in the last years: 865 Greek citizens lived in Luxembourg in 2001 and 2,876 in 2016 (STATEC 2017). The Greek presence in Luxembourg may not seem large, but it is not negligible given that the total population of Luxembourg is 590,667 (STATEC 2017). While the Greek EU employees of the first migration wave tended to enroll their children in the Greek section of the European School, the new migrants often send their children to the trilingual state schools, possibly for financial and educational reasons, where they learn Luxembourgish, German and French in primary school (Gogonas and Kirsch 2016). They learn English in secondary school and, if they wish so, additional languages too. This is also the case of the two families in the present study who recently migrated to Luxembourg following the crisis. The children speak Greek at home and face the challenge of learning several languages in the state primary school. The present article examines these families' ideologies and management strategies and the factors that shape their family language policy (FLP).

\section{Family language policies, ideologies and language management}

Family language policies are complex because they are underpinned by language ideologies, practices and mechanisms for language management which are informed by various agents, processes and factors operating at various 
levels. For instance, language ideologies are influenced by macro-factors (e.g. national language policies, public discourses on bi- or multilingualism), personal beliefs (e.g. the perceived cultural, financial, economic and political value of languages), and personal experiences of using and learning languages (Curdt-Christiansen 2016; Gogonas and Kirsch 2016; Kirsch 2012; Schüpbach 2009). The parents' management decisions, that is the decisions taken to control the language use of others, are similarly shaped by various external and internal factors (Curdt-Christiansen 2012; Spolsky 2007). On a macro-level, they are influenced by socio-political and economic factors as well as educational opportunities to develop home languages. These opportunities depend on national policies, the size of the immigrant group, the density of social networks and the status of the languages at play (Braun and Cline 2014; Curdt-Christiansen 2009). Gallo and Hornberger (2017), for instance, found that the Mexican immigrant children they observed over three years had few opportunities to develop bilingualism and biliteracy in the US schools. These limited opportunities as well as the monolingual ideologies and language policies informed their family language policies. On a micro-level, the parental choices are informed by the parents' linguistic competences, experiences, and ideologies (King and Fogle 2006; Curdt-Christiansen 2016). Studying parents in Israel, Schwartz et al. (2013) reported that the parents' linguistic competences determined the choice of school for their children. Parental competences were also important for the ten Chinese parents who Curdt-Christiansen (2009) studied in Quebec. She found that some parents focused on Chinese while also encouraging the use of other languages because they perceived that their own limited linguistic competences had not contributed to success. Parental aspirations for the children play a significant role as well as shown by Kirsch (2012) who studied the language policies of Luxembourgish parents in the United Kingdom. The parents' experiences with multilingualism, language learning and language, and their expectations that their children should become active multilinguals, informed the opportunities they offered their children to develop multilingual competences. Purkarhofer (2017) examined the aspirations of three parents in Austria, Italy and Hungary whose children had just been or were about to be born. She found that the parents wanted their children to become multilingual and intended to give them some choices in the language planning. Decisions on how to manage patterns of language use and learning opportunities are furthermore influenced by the parents' human and material resources. Braun (2012) and Ruby (2012) illustrated how parents made use of grandparents to transmit the family language and maintain traditions. Other families may regularly go abroad to enhance exposure to the target language and ensure contact with the population (Deprez 2013). 
Many scholars examined the types of policies (e.g. one person-one language or OPOL) as well as their effectiveness. There are different OPOL models, for example, one parent using a minority language and the other one a majority one, or both parents using minority languages. If both parents use the same minority language, they immerse children in that language and provide them with great exposure. This model is known as 'hot-house-approach' (King and Fogle 2013). There are also other models such as both parents using two or more languages.

Literacy practices in the home language are crucial for the development of biliteray and an important part of a FLP. Literacy-related activities with parents or siblings can include joint book reading, language games, familiarization with different language systems, and interactions in different languages around texts (Curdt-Christiansen 2016; Schüpbach 2009). A formal way of developing literacy in the minority language is to enroll children in community classes or bilingual programs, provided they exist, in the country of immigration.

This literature review has shown that FLP are influenced by various external and internal factors. While scholars consider parents to be very important factors or even the most important, researchers have also shown that children can be agents of policy change and socialize their parents into speaking particular languages (Gafaranga 2010; King and Fogle 2013). It is known that older and school-aged children influence the linguistic landscape at home because they bring in the majority language and may therefore decrease opportunities for younger siblings to hear and use the minority languages (Barron-Hauwaert 2011; Braun and Cline 2014; Deprez 2013). Recent studies in the fields of language socialization and FLP have turned to child agency and investigated the ways in which children and parents negotiate family language policies. Studying families in Bolivia, Luykx (2005) reported that the children began to speak Spanish with their Aymara-speaking parents thereby putting pressure on them to switch language. Said and Hua (2017) revealed how two children in an Arabic-English speaking family in the UK enacted their agency by mobilizing their linguistic resources which, in turn, influenced the linguistic choices of their parents and the FLP.

Using a case study approach and drawing on ethnographic methods, the current article seeks to answer the following research questions:

- To what extent do the parents' transnational experiences and language competences shape their family language policies?

- What are the parents' language ideologies and what explicit language management strategies do they deploy? 
The focus of the present small-scale study lies on the parents, their experiences, ideologies and practices and factors influencing these.

\section{Context of the study}

Luxembourg is a trilingual country. As late as 1984, the Languages Law (Mémorial A 1984) gave Luxembourgish, a west-Moselle-Franconian dialect, the status of a language, and made it the national language of the Grand Duchy of Luxembourg. French became the language of legislation while Luxembourgish, German and French became the languages of administration. At that time, Luxembourgish was mainly a spoken language but attempts to standardize it and its ubiquity in the social media have led to an increase in its oral and written use (Gilles and Moulin 2009).

\subsection{Languages in the Luxembourgish education system}

To develop individual multilingualism, the Ministry of Education designed a trilingual education system from primary school. Until 2017, formal and non-formal educational institutions in the early years focused in the main on Luxembourgish because it is perceived to be the bridge to German and the language of integration (Kirsch 2017). Aged 3, children are given the opportunity to develop their Luxembourgish skills in the éducation précoce, a non-compulsory school year. They continue to do so in the following two years of compulsory preschool education. Following new laws in 2017, the national policy changed and teachers and educators working in the précoce and preschool are to introduce children to French and value their home languages. In the first year of primary school, children become literate in German. In Year 2, they are introduced to oral French, and in Year 3 to its written form. Luxembourgish is taught for one hour a week throughout the six years of primary school. Luxembourgish as well as German are the languages of instruction, the latter for the academic subjects. The trilingual system is challenging for all children but particularly for those of ethnic minority background who achieve poorly compared with Luxembourgish children (Martin et al. 2015).

\subsection{The participating families}

Employing ethnographic tools of enquiry, the present study examines the ideologies of two Greek families in multilingual Luxembourg, their explicit 
management strategies and factors affecting their FLP. To recruit research participants, Gogonas, a newcomer to Luxembourg, contacted the Greek Embassy, the Luxembourgish Ministry of Education, the Greek Community of Luxembourg, and the Greek complementary school. These institutions brought him into contact with fifteen families of whom only four fulfilled the following criteria: both parents needed to be Greek; the children needed to attend state Luxembourgish schools, and families needed to have migrated from Greece no more than two years prior to the commencement of the fieldwork in 2014.

Four families participated in the project, but the present article focuses on two families. Family A came to Luxembourg in July 2013. They have two sons, Hector (7) and Andreas (5.5), both born in Greece. The mother Sofia (37) studied graphics and worked at a graphic arts atelier in Athens. She found work as a graphics designer in Luxembourg. Her husband Kostas (37) used to work in Greece as an IT specialist at a Greek Telecommunications Company. In Luxembourg, he works as an IT external collaborator at the European Parliament. Family B is an extended family of seven: Argyro (35), Giannis (42), their three children Elias (4), Despina (8) and Ioulia (10), as well as Argyro's parents Markos (62) and Magda (58). Argyro and Giannis run a Greek restaurant in Luxembourg city. They migrated from Greece to Germany, then to Luxembourg in 2008, before returning to Greece and finally settling in Luxembourg in 2012. Argyro attended secondary school in Germany and left after 18 months. The parents left school without a formal school leaving certificate. Table 1 shows the profile of the families. All first and second names of the families are pseudonyms.

Table 1: Participating families.

\begin{tabular}{|c|c|c|}
\hline & Family A (nuclear) & Family B (extended) \\
\hline Parents' names and ages & Sofia, 37 - Kostas, 37 & $\begin{array}{l}\text { Argyro, } 35 \text { - Giannis, } 42 \text { - Markos, } \\
62 \text { - Magda, } 58\end{array}$ \\
\hline Children's names and ages & Andreas, 5.5 - Hector, 7 & Elias, 4 - Despina, 8 - Ioulia, 10 \\
\hline Time in Luxembourg & 15 months & 2 years \\
\hline Parents' education & $\begin{array}{l}\text { Sofia: Post secondary } \\
\text { vocational education } \\
\text { Kostas: Technical } \\
\text { University }\end{array}$ & Junior High School \\
\hline Parents' occupations & $\begin{array}{l}\text { Sofia: Graphics designer } \\
\text { at a company } \\
\text { Kostas: IT specialist at } \\
\text { European Parliament }\end{array}$ & Restaurant owners \\
\hline
\end{tabular}




\subsection{Data collection and analysis}

We used collaborative ethnography as it privileges an ongoing dialogue between the researcher and the participants. It places the participants at the center and gives them a voice (Lytra 2014). Gogonas used a range of methods to collect data over a period of eight months. Seven semi-structured interviews and informal conversations enabled him to elicit the parents' transnational experiences, language competences, language ideologies and language management strategies. He also engaged in participant observation and collected documents such as emails to gain further insights into their ideologies and management strategies. While interviews provide insights into the families' 'declared practices' (Hélot 2007) and, in our case, their management strategies, observations shed light on the 'actual' practices, that is, what families do.

All interviews were conducted by Gogonas and lasted between 45 and 60 minutes. The use of Greek as well as the fact that interviewer and interviewees had recently migrated to Luxembourg, helped them build a good rapport and eased access into the homes. The parents were keen to share their experiences. When they discovered that the interviewer had been a secondary school teacher in Greece, they came to perceive him as a 'teacher of Greek' and modelled their responses in ways that showed loyalty to their home language. This effect of social desirability was picked up by both researchers. As a result, the first author kept a greater distance and became more critical in his approach. Apart from the parents, Gogonas also interviewed the children. However, he had no opportunities to interview them without a relative being present. The issue of social desirability reappeared as the children said what they believed the relatives wished to hear. These interviews were in the end not used.

Observations and video-recordings in the home and in the Greek restaurant were carried out on a monthly basis to gather information about routine family interactions and literacy activities. Such observations included homework sessions which involved the father in Family A and the mother in family B. In Family A, the father audio- and video-recorded the ways in which he and his eldest son did his homework on three occasions. For instance, he recorded how he helped his sons practice singing German songs and reading the lyrics. In subsequent meetings, he explained the recordings to Gogonas, thereby contextualizing the data. In Family B, Gogonas took detailed field notes and made audio-recordings of the homework sessions involving the mother and the children. The grandparents and the father occasionally observed the activity. In both families, the adults controlled the situation, leaving the children little opportunity to take ownership of learning. 
The present paper draws on a total of 750 minutes of transcribed recordings of interviews and observations. The data were analyzed using thematic analysis to trace emerging themes and critical discourse analysis to explore language ideologies. The themes included transnational experiences, deliberate language choice, code-switching, a focus on language competence and accuracy, the significance of literacy practices in Greek, and the role of the media. These themes were recurrent in the interviews of each family and helped us identify similarities and differences between the families. Nexus analysis (Scollon and Scollon 2004), a type of ethnographic discourse analysis, proved helpful to unpack the different layers and the complexity of the parental discourse. We identified references on different levels, for instance to the economic crisis in Greek, multilingual language ideologies, and theories of language learning calling for language separation.

\section{Findings: Language use, experiences, ideologies and management}

In this section, we compare the two families with regard to their linguistic repertoires, their transnational experiences, cultural practices, and worldviews. We will then examine their language ideologies and compare them with the language management.

\subsection{The parents' transnational experiences and their language use}

Before coming to Luxembourg, Family A resided in the Greek capital. Both Kostas and Sofia perceive themselves as 'world citizens', able to adapt and integrate. Kostas mentions that they are much happier in Luxembourg and enjoy their new lifestyle, having left behind the social malaise brought on by the financial crisis in Greece. While the family members meet with other Greeks in Luxembourg, they also seek opportunities to socialize with Luxembourgers as well as other expats. At home, Kostas and Sofia speak Greek to each other and to the children. According to Kostas, they do so consciously to help their children develop the family language. Being good role-models, the parents continue to develop their own language skills. Kostas, for instance, attended a 6-month language course in German. He claims that he speaks 'very good English' and 'some' German. He used these languages 
when he worked as a business process manager and business consultant in international companies between 2001 and 2006. Sofia attends French language classes and takes private English lessons in Luxembourg. She had studied English and Italian for several years in private language schools back in Greece. She has Italian roots as her father was Italian, but he never spoke to her in his family language.

Unlike Family A, who migrated from Greece to Luxembourg, the parents of Family B have multiple experiences of migration. They came from rural areas of Greece and migrated to Germany where they met at a young age. They lived there until 2004, moved to Luxembourg, and returned to Greece in 2008. Their attempt to run a restaurant in Greece was unsuccessful, so they decided to return to Luxembourg 4 years later. The fact that Argyro's sister and her family lived in Trier, a town in Germany bordering Luxembourg, made their decision to re-emigrate easier. Although the parents had lived in Luxembourg for some time, they do not speak Luxembourgish. They had, however, acquired some German while in Germany. Argyro had learned English at school in Greece and German at her secondary school in Germany. In Luxembourg, she developed basic speaking skills in French. Giannis had learned English at school in Greece. He had also acquired some German while working in his own restaurant in Germany. In Luxembourg, he opened a restaurant too. With the Greek clientele, Giannis and Argyro speak Greek. With other guests they use, when required, German and English. Argyro uses some French too. The Greek restaurant is as a daily meeting point for Greek residents in Luxembourg, a pool from which most of the family's social contacts derive. Unlike Family A, Family B has little time to socialize with the host population and non-Greeks. The grandparents, who live with the family and who speak Greek only, play an important role as linguistic and cultural gatekeepers. At home, Giannis and Argyro use Greek only when speaking to each other, the grandparents and the children. Owing to this language family policy, the children get rich input in Greek.

This brief presentation has shown that the parents of both families are multilingual and able to use Greek, German, English as well as French to various degrees. Similarly, both parents (and the grandparents in Family B) use Greek when addressing their children. The families differ in that Family A tries to forge a cosmopolitan, global identity (Gogonas and Kirsch 2016) while Family B aims for local stability, close family ties and a Greek environment. While there is a Greek Orthodox Church in Luxembourg as well as a Greek Community Centre, none of the family members mentioned them. In the next section, we will show how the parents' differing competences, experiences and worldviews impact on the families' language ideologies. 


\subsection{Language ideologies}

The findings of our data show that the parents value languages in particular ways and hold beliefs about efficient ways of learning languages. We will discuss these factors in turn.

\subsubsection{The parents' perceptions of the value of languages}

In Family A, a key concept permeating Kostas's discourse is 'adaptability'. He believes that skills in several languages are necessary and can enable his two children to integrate into the Luxembourgish society. When asked which of the official languages of Luxembourg he would you like his children to know best, he answers:

Kostas: It depends on whether we stay here forever. We don't plan to move to Germany or Belgium, it will be either here or back to Greece. I always believe in local society integration. As my children were given the chance to live here, I want them to learn Luxembourgish even if it is a useless language as everybody says.

Researcher: Apart from Luxembourgish?

Kostas: As you can see they are learning German and they will learn French, anyway. For me, the key is adaptability and this is a skill they are learning through growing up here. If they have to learn Chinese at some point in their lives because they found a good job opportunity, they can do it, they won't hesitate.

The parents aim to make their children multilingual in the official languages of Luxembourg and develop their skills in Greek. Luxembourgish will help them integrate and Greek maintain their ethnic identity:

Kostas: If we would like to think of Hector as a 'European citizen', then both Luxembourgish and Greek are useless. He could manage with English in both countries realistically talking (...). However, we must not lose our identity, therefore we need to work with Greek in any case. We will speak and write in Greek, this is for sure.

While repeatedly stating that Luxembourgish and Greek are useless from a functional point of view, Kostas recognizes their social and emotional value. At the same time, he stresses the relevance of other world languages such as English and Chinese. He believes that a 'European citizen' has excellent skills in English. Viewing himself as such a 'European citizen' and even a 'citizen of the world' he has the same aspirations for his sons even if this means putting pressure on them: 
Kostas: When it comes to English, I am going to insist. It is the only language that I am going to put pressure on them to learn. I can see how English has helped me to work here, and in other places, it gives you this flexibility. So if I see that they react against learning English, I am going to press them.

The parents in Family B seem to view the three official languages of Luxembourg through an instrumental lens and in relation to the children's job opportunities in Luxembourg. Unlike Family A, they perceive mastery in English as less relevant. According to Argyro, 'English is not so important for getting a job in Luxembourg as is good knowledge of Luxembourgish, French and German'. Both parents have a strong emotional attachment to Greece, its language and culture. They develop the children's competences in Greek for the purpose of communicating and cultivating an ethnic identity. Argyro explains that her children have to be fluent users of Greek because 'they are Greek' and need this language in order to communicate with acquaintances and the family.

Researcher: How important do you think it is that your children know Greek well?

Argyro: Very important.

Researcher: Why?

Argyro: Because we're Greek. Isn't that reason enough?

Researcher: Can you elaborate a bit?

Argyro: It is unthinkable for me, for one not to speak the language of his/her country of origin. And I admire the Portuguese for that. All nationalities here speak their language. The only people I have seen who don't speak their language is the Greek and I don't like that.

Researcher: Do you mean that you would like your children to know also how to read and write Greek or just be able to communicate?

Argyro (emphatically): Definitely. I want them to know the Greek language fluently.

\subsubsection{Perceptions of helpful language practices such as homework}

The parents in both families appear to believe that languages are learned best when they are learned in isolation. This can be inferred from the practices they reported such as ensuring that the children do not code-switch as well as from their decision not to teach literacy in Greek because of possible interferences with German. Furthermore, the parents in both families consider that language learning requires continuous effort both from the learners and from themselves as parents. To illustrate this point, we will show next how parents organize homework sessions with their children. 
The two families spend different amounts of time helping their children with homework and have different linguistic resources at hand. Kostas in Family A has some business competence in German but Sofia has none. Therefore, she sends the children to the Maison Relais pour Enfants (MRE), an educational institution that provides after-school care and help with homework. Although she appreciates the help the children receive, she is concerned because she cannot 'be in charge of the homework in the same way as in Greece'. Kostas is busy during the week and, therefore, devotes his weekends to Hector's homework to boost his language skills. For instance, when Hector learns German and Luxembourgish songs at school, Kostas revises them with him. He asks Hector to read the lyrics because, in his words, 'I want Hector to know what he is singing. I want to ensure that he understands and uses the words correctly'. The following excerpt in Greek (translated into English) and German (in italics), is another example that reveals Kostas's attempts to help Hector understand and pronounce words correctly:

Kostas (excited): Am Ofen ... next to the oven ... Leine.. what is Leine? Let me check in the dictionary. [He finds it]. Hector do you see? Leine means rope, line. So. Am Ofen ... next to the oven ... Ist eine Leine ... there is a rope. Let me make a note of it. Is it die Leine?

Hector (nods).

Kostas: Yes it is. Der Hahn ... You said this means 'rooster' right?

Hector: Yes.

Kostas: Let me make a note of it because I didn't know that.

Kostas: ... Ist auf der Leine ... is on the rope. So the rooster is on a rope next to a stove.

Kostas (trying different pronunciations of the same word): Der Sattel ... or Sattel? (pronounced/satel/and/zatel/)?

Hector: Sattel (/satel/)

Kostas: What does it mean?

Hector: The saddle.

Kostas: Oh yes, you've told me many times but I didn’t remember. Let me write it down.

In this excerpt, Hector has an opportunity to revise several German words and to work on his Greek thanks to the translations. In addition, he can develop language learning strategies that Kostas models for him, such as looking up words in a dictionary, taking notes, memorizing and clarifying. Such strategies can enable him to become an autonomous language learner, a competence necessary both at school and throughout life. The excerpt also illustrates how Kostas picks up some German and acts as a role-model. He explains: 'It is so much fun for me. I also enrich my German vocabulary in this way'. Language 
learning is important for all family members and, as mentioned previously, the parents themselves attend language courses.

This excerpt is representative of other situations and demonstrates that Kostas controls the learning environment without taking account of the children's agency. The youngsters bring in the German homework and implicitly invite the father to work with them but they are not given a choice of how to engage and structure the work session. The parents' perception that they have to assist the children and control homework sessions, must be seen in relation to their expectations. Kostas hopes that his children progress to higher education, which, in turn, means that they will need to go to grammar school if they remain in the state system. Only children with high competences in German and French are able to enroll in these schools in Luxembourg.

In Family B, Giannis does not get involved in his children's homework because he works long hours. The same is true for Argyro but she nevertheless, in her words, 'steals' approximately one hour every afternoon to assist her children. Like Sofia, she perceives a need to control homework sessions because, as she reports, 'I want to know how they are doing at school.' Although her German literacy skills are more developed than her husband's, she rates her overall competence in German and French as weak. The observations of the homework sessions involving Argyro and Ioulia, showed that Argyro inferred the meaning of German words she did not know rather than resorting to dictionaries or the Internet. Argyro's linguistic skills are not advanced enough to help the children learn French either. Unlike Sofia in family B, she is unable to attend language classes. Nevertheless, she helps the children by occasionally asking a neighbor to assist with homework in French. This testifies both to her endeavor to help the children succeed and to her thoughtful manner of managing the use of multiple languages at home.

This section then has shown that both parents' ideologies are shaped by their past and present transcultural and linguistic experiences. The parents voice strong beliefs regarding the value of particular languages and perceive language learning as an ongoing process requiring effort and assistance. They help children with homework thereby controlling the interactions. The following sections illustrate further strategies used by the parents to manage the children's language use and learning process.

\subsection{Language management}

In this section, we examine how the two families' language ideologies impact on their language management and, in particular, on their day-care organization, 
the discourse strategies, and the ways in which they develop their children's competence in Greek.

\subsubsection{Day-care organization}

The Maison Relais pour Enfants (MRE) functions in effect as a social center facilitating the learning of Luxembourgish and assisting children with their homework. Kostas and Sofia appreciate the MRE and regularly send their children there. In Sofia's words:

The two ladies at our Maison Relais are really nice. Besides, there are not too many kids so they can devote time to them.

Owing to the MRE, the children have an opportunity to learn Luxembourgish. In addition, Hector, the older boy, can also get help with homework in German.

By contrast, the parents in Family B do not consider it necessary for their children to attend the MRE. They explain that the grandparents who live with them can take care of the children. Argyro prefers her children to have some quality time with family members and to spend more time in the Greek environment. The grandparents speak Greek only, despite having lived in Germany where Argyro and her siblings acted as language brokers at the time (Antonini 2016). Given the grandparents' linguistic resources, the children will continue to develop this language. As previously seen, the parents believe that it helps them maintain their linguistic identity.

\subsubsection{Media as a teaching tool}

TV and Internet are teaching tools in both families; Family A develops German and Family B Greek. As Sofia does not speak German, the school language she perceives the parents must consolidate at home, she deploys a 'media approach' to language management. For example, she uses the Internet to search for and play the German songs that the boys have learnt at school. Moreover, she had decided that the boys should watch German instead of Greek television. She believes that TV can 'immerse' the boys in German.

The parents and the grandparents in Family B have designed a context of immersion in Greek because they believe that it is their duty to teach the children the family language. All members watch Greek television on the Internet and the satellite. During a home visit while the TV was on, Ioulia told Gogonas that she liked watching the Greek channels and that these also showed 
English programs with subtitles. When asked whether she also watched German programs, the grandfather intervened:

Grandfather: German TV here? I haven't installed it. They don't need to hear either German or Luxembourgish here at home, they do that at school. Here they need to hear Greek. I could have installed Luxembourgish TV so that I would learn a few things but the point is not for me to learn: the point is for them to learn.

This comment indicates the grandfather's perception that languages can be and must be separated: Greek is the language used at home and Luxembourgish, German and French are limited to the domain of school. He seemed to have forgotten that the latter languages are also the languages used daily in Luxembourg.

\subsubsection{Code-switching and parental discourse strategies}

The children in Family A have been in Luxembourg for 15 months. As they attend a state school as well as the MRE, they get regular input in Luxembourgish and, in the case of Hector, German. They encounter Greek at home, after school and during the weekends and holidays. The input in Greek is less frequent in Luxembourg than in Greece, which is beginning to have an impact on the children's competence. Kostas notices that the boys have forgotten some Greek words.

Kostas: The other day I asked Hector to name the 4 seasons and he didn't remember the Greek word for 'autumn' and instead he used the word Herbst. Sometimes they ask me 'can I say it in Luxembourgish'?

Researcher: How do you respond to these requests?

Kostas: I let them say it in Luxembourgish and then I teach them the Greek word. I also learn the Luxembourgish word like this. They love teaching me Luxembourgish.

The father does not appear upset when the children use German or Luxembourgish words when they cannot find the Greek ones. He perceives these occasions as learning opportunities both for the children - to improve their Greek - and for himself - to learn Luxembourgish. By contrast, Sofia is less comfortable when the children address her in whole sentences in Luxembourgish. She explains: 'I don't encourage it. I tell them mum doesn't know this language, so you will speak to me in Greek'. She reminds the boys that she does not understand them and requires them to speak Greek. By contrast, she lets the children use Luxembourgish when they play or engage in word games. In her words: 'They ask each other "Do you know this word? Is it German or Luxembourgish? Why do you know it when I don't?” There's a sort of competition between them. It's a game. I don't stop them.' 
In line with their language ideologies, the parents and grandparents in Family B do not tolerate the use of languages other than Greek in interactions between children and adults.

Researcher: Does it ever happen that your children say some words in another language?

Argyro: No, maybe sometimes merci or danke but never a whole sentence.

Researcher: What if she talks about school stuff? Doesn't she use German then?

Argyro: No, no, she tries to describe everything in Greek. I help them find the words, especially the younger one. The eldest, Ioulia, has a rich vocabulary in Greek.

Giannis: The children will learn that at this table we speak only Greek and at that table with their friends they can speak Luxembourgish. My daughters reply to me in German? Not even in 300 years if I live so long!

Argyro: The very first time your child speaks to you in another language you will correct him/her. You will say “repeat it in Greek, I don't understand”. If you allow this to happen once, then it will be happening all the time.

Similarly to the mother in Family A, all adults in Family B pretend not to understand languages other than Greek in order to make their children speak Greek. They ensure that all interactions within the family are in Greek.

\subsubsection{Literacy practices in Greek}

Kostas could imagine enrolling his children at the European school, for example, in the Greek section. However, this depends on the children's skills in Greek and it would only happen if they cannot get into any of the trilingual grammar schools. It would be important, therefore, to develop the children's skills in Greek, including literacy. Kostas teaches the children Greek through games such as riddles or hangman, and reads stories in Greek to them. The parents have considered finding a private tutor who can teach Greek in an enjoyable manner as well as sending the children to the Greek complementary school once both master literacy in German. Sofia explains:

(Sending them to Greek complementary school) won't happen before two years from now, because I would like Andreas to finish the first grade of primary school first so that he also gets a good grounding in German, like his elder brother. After that, the two boys might enroll in Greek classes. I see that Hector confuses the alphabet. When he wants to write something he always starts writing in German because he feels more confident, but then he gets confused and uses some Greek letters instead of Latin. He uses a Latin 'm', for example, instead of [the Greek] ' $\mu$ '. This makes me think that he'd better grasp German first, and then he will also deal with Greek. 
This excerpt illustrates Sofia's perception that the process of becoming literate in Greek may impede the children's writing skills in German. As a result, the parents prefer to delay Greek classes. At the same time, they have some reservations because they heard that the teaching is rather formal and they prefer not to 'overburden the children with school-like activities'.

As already seen, Greek plays an important role in Family B. Like Kostas, Argyro reads stories in Greek to her children, but unlike him, she believes that this is not enough to develop the language to a high standard. She welcomes the existence of the complementary school that, in her eyes, can make the children competent in Greek and teach them about Greek culture. She therefore sent the two oldest children to the Greek complementary school as soon as they arrived in Luxembourg. The youngest child is not old enough to attend the complementary school at the beginning of the data collection. Argyro has not yet thought about higher education for her children. She claims: 'University is not for everybody. I don't mind if they don't study, as long as they're happy'.

This section shows that the parents' ideologies are largely in line with their management strategies. Each family has found ways to organize the children's day care and found opportunities to develop particular languages in line with their 'multilingual' or 'mainly-Greek' language policy.

\section{Discussion and conclusion}

This study explores parental experiences, language ideologies and management. We argue that language ideologies and, in turn, practices are 'constructed from the sociocultural experience of the speaker' (Kroskrity 2004: 496), as well as being related to their experiences, world views and their competences. For instance, parents in both families have good communication skills in Greek and do not risk losing their language. In Family B, Greek is the language that holds the family together and, therefore, there are strong emotions connected to it (Tannenbaum 2005; Wong Fillmore 2000). The grandparents play a particularly important role as they immerse the children in a Greek cultural and linguistic environment (Braun 2012; Ruby 2012). As such, they provide input and motivate the children to use Greek.

Further, the differing cultural identification of the families with the country of origin may account for the different emphasis placed on Greek language maintenance. Schwartz et al. (2010) explained that cultural identification with the host country and the country of origin are significant factors in the formation of FLP. Drawing on Pease-Alvarez (2003), they revealed that the Mexicans' 
desire to integrate in California led them to emphasize the use of English with their children. The parents of Family A in the present article have an integrative attitude to living in Luxembourg. Their past professional experiences and their wish to have a different lifestyle reinforce their desire to improve their own and their children's social standing, making the most of the multicultural and multilingual environment that Luxembourg offers. These factors result in a weak management approach regarding Greek and an overt 'multilingual language policy'. Greek is spoken daily but Greek literacy is postponed for now, particularly because the parents assist the eldest son in developing oral and written skills in German. At the MRE, the children are given opportunities to develop Luxembourgish and German through daily interactions.

The parents and grandparents of Family B, on the other hand, have a strong cultural identification with Greece, which they maintain in Luxembourg. Their restaurant seems to be a symbol of their ethnic identity. Appadurai (1988) and Helstosky (2004) hold that national cuisines are discursively produced as tools of nation-building and signifiers of national culture. Their ethnic food plays the role of a bonding agent in culturally and geographically displaced communities (Arvela 2013: 2). The restaurant gives them ample opportunities to socialize with their co-ethnics and enabled them to create a real Greek community rather than an 'imagined community' (Kanno and Norton 2003). At home, they have an overt language policy that emphasizes the use of Greek.

The findings have further shown that parents in both studies hold strong language ideologies. The parents of Family A have experienced the benefits of multilingualism and intend to make their children multilingual. This finding is in line with other studies (Kirsch 2012; Curdt-Christiansen 2013). Although the parents of the present study were multilingual, they nevertheless perceived that languages needed to be learned in sequence, each one kept separate from the others. A strict separation of languages was assumed to be the only way to avoid 'cross-contamination' (Jacobson and Faltis 1990). As a result, the model 'one person - one language' (Ronjat 1913) guided language policies in these bilingual homes. The parents in Family B used a 'hot-house' approach (King and Fogle 2013) and requested that interactions between family members are in Greek only. Given the parents' lack of understanding of Luxembourgish, it was understandable that they used a 'minimal grasp strategy' (Lanza 2004) when the children used words they did not know. They required the children to speak Greek. The parents' perspective on bilingualism and bilingual language acquisition is reminiscent of the conservative view of bilingualism prevalent in the nineteenth century, which is in stark contrast to a dynamic view suggested in the twentyfirst century (García 2009). Rather than understanding languages as discrete 
objects, scholars conceptualize them as fluid, complex, and dynamic processes (García 2009; Jørgensen et al. 2011). Today, 'translanguaging', meaning shuttling between the languages, is considered to be a natural practice amongst bilinguals (García 2009).

Both families made a real effort to help children with their homework, following a belief that they needed to control homework sessions. This belief seems to be culture-specific. Researchers reported that Greek parents highly value homework (Sebastian 1989) and that the Greek education system expects parents to be involved in the children's homework (Gogonas 2010). The parents in the present study also highlight the importance of the complimentary schools in the maintenance and in the further development of the children's skills in Greek. This is especially true of Family B where complementary schools are seen as an important means of developing a Greek linguistic and cultural identity. From this perspective, the two Greek families have adopted measures similar to those of the parents researched by, for example, Lytra (2014), and Schwartz et al. (2010, 2013).

The findings of the present study have emphasized the role of the parents, particularly as they let the children take little control over their homework sessions. The children brought languages other than Greek into the home and made their parents engage in homework activities with them but the children were not driving these interactions. Contrary other studies by Gafaranga (2010), Gallo and Hornberger (2017), King and Fogle (2013), Luykx (2005), and Said and Hua (2017), we have not found that the children's agency influenced family language policies. Our finding can be explained in parts by its focus, which was on adults, and the methods. Because the children were interviewed in the presence of the parents, they said what they thought would please their parents. In addition, one of the parents offered to record homework sessions with the children and he may, therefore, have focused on himself and the ways in which he supported language learning. We conclude that researchers are more likely to collect data on child agency if they interview children with no parent present and observe interactions between adults and children in a range of contexts.

Finally, the findings of this study have illustrated that the relationship between language ideologies and language management differed in the two families. Researchers have shown that language ideologies are not always congruent with practices (King 2000; Kirsch 2012; Schwartz 2008). The parents in Family A appear to perceive the role of Greek in contradictory terms. While they consider Greek to be important both for the children's identity and for educational reasons, they nevertheless put little emphasis on its development, at least at the time of writing this paper. In Family B, there seems to be coherence between ideologies and management of Greek. However, this may change in the 
future, when the children develop their competences in Luxembourgish, German and French, and socialize with Luxembourgish-speaking friends. At that moment, they may introduce more school languages and literacies into the home, which, in turn, is likely to change the languages of communication among the siblings and affect the family language policies (Barron-Hauwaert 2011; Braun and Cline 2014; Deprez 2013; King and Fogle 2006; Wong Fillmore 2000). The children in Family B may even become language brokers for the grandparents (Antonini 2016).

This study has contributed to the field of FLP by shedding light on the interplay between internal and external factors that influenced family language management. The outcomes of this and further studies are particularly important for educators as they provide insights into the migrant children' linguistic experiences and competences, which, in turn, may encourage them to develop more inclusive, multilingual approaches.

Acknowledgements: We would also like to thank Prof. Xiao Lan CurdtChristiansen, Prof. Elisabeth Lanza and the reviewers for their supportive feedback.

Funding: This research project was funded by the Fonds National de la Recherche in Luxembourg [grant number 6791471] and abided by the ethical principles of the University of Luxembourg.

\section{References}

Antonini, Rachele. 2016. Caught in the middle: Child language brokering as a form of unrecognized language service. Journal of Multilingual and Multicultural Development. doi:10.1080/01434632.2015.1127931

Appadurai, Arjun. 1988. How to make a national cuisine: Cookbooks in contemporary India. Comparative Studies in Society and History 30(1). 3-24.

Arvela, Paula. 2013. Ethnic food: The other in ourselves. In Don Sanderson \& Mira Crouch (eds.), Food: Expressions and impressions, 45-56. Oxford, United Kingdom: Inter-Disciplinary Press.

Barron-Hauwaert, Suzanne. 2011. Bilingual sibling: Language Use in Families. Bristol: Multilingual Matters.

Braun, Andreas. 2012. Language maintenance in trilingual families - A focus on grandparents. International Journal of Multilingualism 9(4). 423-436.

Braun, Andreas \& Tonie Cline. 2014. Language strategies for trilingual families. Bristol: Multilingual Matters. 
Curdt-Christiansen, Xiao Lan. 2009. Invisible and visible language planning: Ideological factors in the family language policy of Chinese immigrant families in Quebec. Language Policy 8. 351-375.

Curdt-Christiansen, Xiao Lan. 2012. Private language management in Singapore: Which language to practice and how?. In Alexander Seeshing Yeung, Cynthia F.K. Lee \& Elinor L. Brown (eds.), Communication and language, 55-77. Scottsdale, AZ: Information Age Publishing.

Curdt-Christiansen, Xiao Lan. 2013. Negotiating family language policy: Doing homework. In Mila Schwartz \& Anna Verschik (eds.), Successful family language policy: Parents, children and educators in interaction, Multilingual Education, 7. 277-295. Dordrecht, Netherlands: Springer.

Curdt-Christiansen, Xiao Lan. 2016. Conflicting language ideologies and contradictory language practices in Singaporean multilingual families. Journal of Multilingual and Multicultural Development. doi:10.1080/01434632.2015.1127926

Deprez, Christine. 2013. Les enfants bilingues: Langues et familles. Paris: Didier.

Droulia-Mitrakou, Elli. 2006. Luxembourg. In Ioannis Hasiotis, Olga Katsiardi-Hering \& Evridiki Abatzi (eds.), Greeks in the Diaspora 15th-21st century, 134-135. Athens: Hellenic Parliament Publications [in Greek].

Gafaranga, Joseph. 2010. Medium request: Talking language shift into being. Language in Society 39. 241-270.

Gallo, Sarah \& Nancy Hornberger. 2017. Immigration policy as family language policy: Mexican immigrant children and families in search of biliteracy. International Journal of Bilingualism. doi:10.1177/1367006916684908

Garcîa, Ofelia. 2009. Bilingual education in the twenty-first century: A global perspective. Malden, MA: Wiley-Blackwell.

Gilles, Peter \& Claudine Moulin. 2009. Die soziale praxis der mehrsprachigkeit in Luxemburg. Handbuch der sozialen Arbeit in Luxemburg. In Helmut Willems (ed.), Handbuch der sozialen und erzieherischen Arbeit in Luxemburg, 197-121. Luxembourg: Saint-Paul.

Gogonas, Nikos. 2010. Bilingualism and multiculturalism in Greek Education. Investigating ethnic language maintenance among pupils of Albanian and Egyptian origin in Athens. Newcastle upon Tyne: Cambridge Scholars.

Gogonas, Nikos \& Claudine Kirsch. 2016. 'In this country my children are learning two of the most important languages in Europe': Ideologies of language as a commodity among Greek migrant families in Luxembourg. International Journal of Bilingual Education and Bilingualism. doi:10.1080/13670050.2016.1181602

Hélot, Christine. 2007. Du bilinguisme en famille au bilinguisme à l'école. Paris: L'Harmattan. Helstosky, Carol. 2004. Garlic and oil. Politics and food in Italy. Oxford: Berg.

Jacobson, Rodolfo \& Christian Faltis. 1990. Language distribution issues in bilingual schooling. Clevedon: Multilingual Matters.

Jørgensen, Jen, Martha Sif Karrebæk, Lian Malai Madsen \& Janus Spindler Møller. 2011. Polylanguaging in superdiversity. Diversities 13(2). 23-38.

Kanno, Yasuko \& Bonny Norton. 2003. Imagined communities and educational possibilities: Introduction. Journal of Language, Identity, and Education 2(4). 241-249.

King, Kendall A. 2000. Language ideologies and heritage language education. International Journal of Bilingual Education and Bilingualism 3(3). 167-184. 
King, Kendall A. \& Lyn Fogle. 2006. Bilingual parenting as good parenting: Parents' perspectives on family language policy for additive bilingualism. International Journal of Bilingual Education and Bilingualism 9(6). 695-712. doi:10.2167/beb362.0

King, Kendall A. \& Lynn Fogle. 2013. Family language policy and bilingual parenting. Language Teaching 46(2). 172-194.

Kirsch, Claudine. 2012. Ideologies, struggles and contradictions: An account of mothers raising their children bilingually in Luxembourgish and English in Britain. International Journal of Bilingual Education and Biligualism 15(1). 95-112.

Kirsch, Claudine. 2017. Young children capitalising on their entire language repertoire for language learning at school. Language, Culture and Curriculum. doi:10.1080/ 07908318.2017.1304954

Kroskrity, Paul V. 2004. Language ideologies. In Alessandro Duranti (ed.), Companion to linguistic anthropology, 496-517. Malden, MA: Basil Blackwell.

Labrianidis, Lois \& Nikos Vogiatzis. 2013. Highly skilled migration: What differentiates the 'brains' who are drained from those who return in the case of Greece? Population, Space and Place 19(5). 472-486.

Lanza, Elizabeth. 2004. Language mixing in infant bilingualism. A sociolinguistic perspective. Oxford Studies in Language Contact. Oxford: Oxford University Press.

Luykx, Aurolyn. 2005. Children as socializing agents: Family language policy in situations of language shift. ISB4: Proceedings of the 4th International Symposium on Bilingualism.

Lytra, Vally. 2014. Revisiting discourses of language, identity and community in a transnational context through a commemorative book project. Multilingua 33(5-6). 551-574.

Made Mbe, Annie Flore. 2014. Parents' representations of the family language policy within bilingual families in Luxembourg: Choices, motivations, strategies and children's language development. In Kristine Horner, Ingrid. de Saint-Georges \& Jean-Jacques Weber (eds.), Multilingualism and mobility in Europe: Policies and practices, 189-203. Frankfurt/Main Peter Lang.

Martin, Romain, Sonja Ugen \& Antoine Fischbach. 2015. Epreuves standardisées: Bildungsmonitoring für Luxemburg. Nationaler Bericht 2011 bis 2013. LUCET. http://www. epstan.lu/cms/images/downloads/Ergebnisse/Fondamental/EpStan\%202013-2014/ EpStan\%202011-2013\%20-\%20Nationaler\%20Bericht.pdf (accessed 16 October 2015).

Mémorial A nº 244 de 2010 1984. http://legilux.public.lu/eli/etat/leg/memorial/2010/244

Pease-Alvarez, Lucinda. 2003. Transforming perspectives on bilingual language socialization. In Robert Bayley \& Sandra R. Schecter (eds.), Language socialization in bi-and multi-lingual societies, 9-24. Clevedon, England: Multilingual Matters.

Purkarhofer, Judith. 2017. Building expectations: Imagining family language policies and heteroglossic social spaces. International Journal of Bilingualism (09.02.2017). doi:10.1177/ 1367006916684921

Ronjat, Jules. 1913. Le développement du langage observé chez un enfant bilingue. Paris: Librairie Ancienne H. Champion.

Ruby, Mahera. 2012. The role of a grandmother in maintaining Bangla with her granddaughter in East London. Journal of Multilingual and Multicultural Development 33(1). 67-83.

Said, Fatma \& Zhua Hua. 2017. No, no Maama! say “shaatir ya ouledee shaatir”!": Children's agency and creativity in language use and socialisation. International Journal of Bilingualism (09.02.2017). doi:10.1177/1367006916684919

Schüpbach, Doris. 2009. Language transmission revisited: Family type, linguistic environment and language attitudes. International Journal of Bilingual Education and Bilingualism 12. 1-15. 
Schwartz, Mila. 2008. Exploring the relationship between family language policy and heritage language knowledge among second generation Russian-Jewish immigrants in Israel. Journal of Multilingual and Multicultural Development 29. 400-418.

Schwartz, Mila, Victor Moin \& Mark Kayle. 2013. Parent's choice of a bilingual hebrew-Arabic kindergarden for the children. In Mila Schwarz \& Anna Verschik (eds.), Succesfull family language policy: Parents, children and educators in interaction, 23-51. Dordrecht, The Netherlands: Springer.

Schwartz, Mila, Victor Moin, Mark Leikin \& Anna Breitkopf. 2010. Immigrants' family language policy toward children's preschool bilingual education: Parents' perspective. International Multilingual Research Journal 4. 107-124.

Scollon, Ron \& Suzie Wong Scollon. 2004. Nexus analysis: Discourse and the emerging internet. London: Routledge.

Sebastian, Tania. 1989. The home-school interface parental and teacher beliefs about homework from a multicultural perspective. Theses and Dissertations (Comprehensive). Paper 546. http://scholars.wlu.ca/etd/546

Spolsky, Bernard. 2007. Family language management: Some preliminaries. In Anat Stavans \& Irit Kupferberg (eds.), Studies in language and language education: Essays in honor of Elite Olshtain, 429-449. Jerusalem: The Magnes press, Hebrew University.

STATEC. www.statistiques.public.lu (accessed April 2017).

Tannenbaum, Michael. 2005. Viewing family relations through a linguistic lens: Symbolic aspects of language maintenance in immigrant families. The Journal of Family Communication 5(3). 229-252.

Triandafyllidou, Anna \& Ruby Gropas. 2014. 'Voting with their feet': Highly skilled emigrants from Southern Europe. American Behavioral Scientist 58(12). 1614-1633.

Wong Fillmore, Lily. 2000. Loss of family languages: Should educators be concerned? Theory into Practice 39(4). 203-210. 